ISSN 0258-7122

Bangladesh J. Agril. Res. 34(3) : 417-424, September 2009

\title{
EFFECT OF IRRIGATION FREQUENCY AND FUNGICIDE SPRAY ON YIELD AND DISEASE INFECTION OF ONION
}

\author{
S.K. BISWAS ${ }^{1}$, M.A. RAZZAQUE AKANDA ${ }^{2}$ \\ M. RAFI UDDIN ${ }^{3}$ AND P. K. SARKER ${ }^{2}$
}

\begin{abstract}
A two-year field experiment was conducted at Regional Agricultural Research Station, Jessore during the rabi seasons of 2002-2003 and 2003-2004 to find out the level of disease incidence under different levels of irrigation and fungicide spray on the bulb yield of onion. Four irrigation levels: no irrigation $\left(\mathrm{I}_{1}\right)$, irrigation at 10 days interval $\left(\mathrm{I}_{2}\right), 20$ days interval $\left(\mathrm{I}_{3}\right)$, and 30 days interval $\left(1_{4}\right)$ with 4 spray schedules: no spray $\left(F_{1}\right)$, one spray at 40 days after transplanting (DAT) $\left(\mathrm{F}_{2}\right)$, two sprays each at 40 and 55 DAT $\left(\mathrm{F}_{3}\right)$ and three sprays each at 40,55 , and 70 DAT $\left(\mathrm{F}_{4}\right)$ were used. Yield and yield attributes varied significantly ( $\mathrm{p}=0.05$ ) between sprayed and unsprayed, and irrigated and non-irrigated treatments, respectively. Higher yields were obtained with the higher frequencies of irrigation and spray. Application of fungicide reduced the disease severity significantly, while irrigation had no significant effect on disease infection. But there was a decreasing trend of the disease severity with increasing irrigation frequency. The highest bulb yield of onion (12.45 t/ha) was obtained with a total water use of $245 \mathrm{~mm}$ in six applications including an effective rainfall of $16 \mathrm{~mm}$ and three sprays. The disease severity between sprayed and unsprayed plots ranged from 1.33 to 3.16 for $I_{1}, 1.08$ to 2.33 for $I_{2}$ 1.16 to 2.83 for $\mathrm{I}_{3}$, and 1.16 to 3.00 for $\mathrm{I}_{4}$, respectively.
\end{abstract}

Key Words: Onion, disease incidence, irrigation, water use efficiency.

\section{Introduction}

Onion (Allium cepa L.) is one of the major spices crops as well as a vegetable in Bangladesh. It is grown in about 37,650 hectares of land and produces 1.53 lac metric tons annually (BBS, 2004). This production is much less than the annual requirement of about 7.5 lac metric tons. The deficit amount is being met up by importing it in exchange of considerable amount of foreign currency. A large portion of this deficit can be attenuated by increasing the per hectare yield. In the country like Bangladesh, where rainfall is erratic and scarce in the winter, irrigation becomes indispensable for a good production of onion. But farmers are often reluctant to apply any irrigation or they apply insufficient irrigation in fear of disease severity of onion. As a result, the average yield of onion is very low (4.06 t/ha) as compared to that of other onion producing countries (FAO, 2001)

${ }^{1}$ Scientific Officer, ${ }^{2}$ Senior Scientific Officer, Irrigation and Water Management Division, BARI, Joydebpur, Gazipur-1701, ${ }^{3}$ Senior Scientific Officer, HRC, RARS, BARI, Jessore- 7400, Bangladesh. 
like the Republic of Korea (61.91 t/ha), the Netherlands (54.13 t/ha), Japan (44.44 t/ha) and the USA (44.14 t/ha). The yield of onion can be augmented by proper management practices, especially emphasizing on irrigation and disease management.

Onion is afflicted by a large number of diseases of which leaf purple blotch caused by Alternaria porri (Ellis) Cif. is found all over and considered most destructive in Bangladesh. The disease attacks both aerial and underground parts at field conditions (Ahmed and Hossain, 1985; Bose and Some, 1986; Meah and Khan, 1987; Rahman et al., 1988; Ashrafuzzaman and Ahad, 1976). Severe infection may result in complete drying of the foliage, which ultimately causes considerable yield losses due to the reduction of green plant parts (Ghuge et al., 1980). Many investigations have been done to control the disease of onion by spraying chemicals but a very few references on irrigation and disease interaction is available. This experiment was, therefore, undertaken to investigate the effect of irrigation frequency and fungicide spray on the disease incidence as well as yield of onion.

\section{Materials and Method}

A field experiment was conducted at Regional Agricultural Research Station, Jessore during the rabi season of 2002/03 and 2003/04. The soil of the experimental field was silty loam in texture having field capacity, 27.50 percent and bulk density, $1.48 \mathrm{~g} / \mathrm{cc}$. The experiment comprised of four irrigation treatments viz., no irrigation $\left(\mathrm{I}_{1}\right)$, irrigation at $10\left(1_{2}\right), 20\left(1_{3}\right)$, and 30 days intervals $\left(1_{4}\right)$ as main factor and four fungicide spray treatments viz., no spray $\left(F_{1}\right)$, one spray with $2 \%$ Rovral at 40 days after transplanting (DAT) $\left(F_{2}\right)$, two sprays each at 40 and 55 DAT $\left(\mathrm{F}_{3}\right)$ and three sprays each at 40,55 , and 70 DAT $\left(\mathrm{F}_{4}\right)$ as sub-factor. These were laid out in split-plot design with three replications.

The unit plot size was $3 \mathrm{~m} \times 2 \mathrm{~m}$ and the row and plant spacings were $20 \mathrm{~cm}$ and $10 \mathrm{~cm}$, respectively. The seedlings of onion were transplanted on 05 January 2003 and 02 January 2004. Fertilizer application rates were 90, 75, 120, and 20 $\mathrm{kg} / \mathrm{ha}$ of $\mathrm{N}, \mathrm{P}_{2} \mathrm{O}_{5}, \mathrm{~K}_{2} \mathrm{O}$ and S, respectively. One-third of $\mathrm{N}$ in the form of urea and full $\mathrm{P}_{2} 0_{5}, \mathrm{~K}_{2} \mathrm{O}$ and $\mathrm{S}$ in the form of triple super phosphate (TSP), muriate of potash (MOP) and zypsum, respectively, were applied at the time of final land preparation. The remaining two- thirds of urea were applied at 25 and 50 DAT as top dress. Soil moisture was determined before transplanting and after harvest to fmd out the amount of soil moisture depletion. It was also monitored before irrigations to estimate the amount of irrigation water needed to bring the soil moisture to field capacity. Measured quantity of irrigation water was applied to individual plot. Disease severity was recorded following the rating scale (0-5) as described below (Sharma, 1986): 
$0=$ No disease symptoms;

$1=$ A few spots towards the tip, covering less than $10 \%$ leaf area;

$2=$ Several dark purplish brown patches covering less than 20\% leaf area;

$3=$ Several patches with paler outer zone covering up to $40 \%$ leaf area;

$4=$ Long streak covering upto $75 \%$ leaf area or breaking of the leaves from the centre; and

$5=$ Complete drying of the leaves or breaking of the leaves from the base.

The crop was harvested on 31 March 2003 and 28 March 2004. All necessary data were recorded and analyzed statistically using MSTAT-C programme. Pooled analyses were done over the years, because, no significant difference was found between them.

\section{Results and Discussion}

\section{Yield and yield attributes}

The yield and yield attributing parameters like plant height, number of leaves/plant, unit weight of bulb and biomass yield varied significantly among the irrigation treatments (Table 1). Plant population showed no significant variation as crop establishment was ensured applying a common irrigation to all treatments just after transplanting of seedlings.

Plant height and leaves per plant increased almost linearly with increasing the number of irrigation. These parameters were found maximum in the treatment which received irrigation at 10 days interval $\left(1_{2}\right)$ and minimum in non-irrigated control treatment. A similar trend was observed in unit weight of bulb. Weight of single bulb was found more in irrigated treatments. Like other parameters, biomass and bulb yields were found to increase with increased frequencies of irrigation. The yield increase in irrigated treatments over the control ranged from 75.96 to $197.67 \%$. The highest yield (11.52 t/ha) of bulb was obtained from $1_{2}$, receiving irrigation at 10 days interval, while the lowest (3.87 t/ha) was obtained from non-irrigated treatment. It could be inferred that bulb yield of onion increases with increasing levels of irrigation upto a certain limit. Islam et al. (1997) and Biswas et al. (2003) reported similar result for onion. Plants that received irrigation had better vegetative growth and thereby yielded higher biomass than that of non-irrigated plants.

In contrast to irrigation treatments, application of fungicide had no significant influence on plant height and number of leaves per plant. Unit bulb weight, biomass yield and bulb yield of onion varied significantly with fungicide spray. But the variation was not pronounced as it was observed in irrigation treatments. However, the unit weight of bulb and the biomass yield were found 
the highest in the treatment sprayed three times $\left(\mathrm{F}_{4}\right)$ and it was identical with the treatment sprayed twice $\left(\mathrm{F}_{3}\right)$. The lowest values of these parameters were realized in unsprayed treatment. The similar trend was observed in bulb yield (Table 1). Interaction of irrigation and fungicide showed significant effects on yield and almost all yield contributing parameters (Table 2). Plant height, number of leaves/plant, unit weight of bulb, biomass and bulb yield were increased with increasing frequency of irrigation and fungicide spray. The highest yield (12.45 $\mathrm{t} / \mathrm{ha}$ ) was obtained in the treatment which was irrigated six times and sprayed three times $\left(1_{2} \mathrm{~F}_{4}\right)$ and the lowest yield $(3.44 \mathrm{t} / \mathrm{ha})$ was found in the treatment which received no irrigation and no fungicide spray $\left(1_{1} F_{1}\right)$.

Table 1. Effect of irrigation and fungicide spray on yield, yield attributes and disease incidence of onion (average of 2 years).

\begin{tabular}{|c|c|c|c|c|c|c|c|c|}
\hline Treatments & \begin{tabular}{|c} 
Plant \\
population \\
$\left(\right.$ no. $\left./ \mathrm{m}^{2}\right)$
\end{tabular} & $\begin{array}{c}\text { Plant } \\
\text { height } \\
(\mathrm{cm})\end{array}$ & $\begin{array}{c}\text { Leaves/ } \\
\text { plant } \\
\text { (no.) }\end{array}$ & $\begin{array}{c}\text { Unit } \\
\text { bulb } \\
\text { wt } \\
\text { (g) }\end{array}$ & \begin{tabular}{|c} 
Disease \\
score \\
(Scale: \\
$0-5$ )
\end{tabular} & $\begin{array}{c}\text { Biomass } \\
\text { yield } \\
\text { (t/ha) }\end{array}$ & $\begin{array}{l}\text { Bulb } \\
\text { yield } \\
\text { (t/ha) }\end{array}$ & \begin{tabular}{|c} 
Yield \\
increase \\
over \\
control \\
$(\%)$
\end{tabular} \\
\hline \multicolumn{9}{|l|}{ A. Irrigation } \\
\hline $\mathrm{I}_{1}$ & 48.62 & 41.26 & 4.87 & 12.43 & 2.00 & 0.26 & 3.87 & - \\
\hline $\mathrm{I}_{2}$ & 49.17 & 54.81 & 7.37 & 29.02 & 1.60 & 0.70 & 11.52 & 197.67 \\
\hline $\mathrm{I}_{3}$ & 49.34 & 53.24 & 7.15 & 23.37 & 1.79 & 0.56 & 9.37 & 142.11 \\
\hline $\mathrm{I}_{4}$ & 48.65 & 47.95 & 5.7 & 18.22 & 1.91 & 0.37 & 6.81 & 75.96 \\
\hline LSD (0.05) & ns & 3.12 & 0.611 & 5.10 & ns & 0.118 & 1.19 & - \\
\hline CV (\%) & 3.37 & 6.33 & 9.75 & 8.49 & 12.33 & 14.75 & 8.44 & - \\
\hline \multicolumn{9}{|l|}{ B. Fungicide } \\
\hline $\mathrm{F}_{1}$ & 48.79 & 8.99 & 6.20 & 19.35 & 2.83 & 0.406 & 7.05 & - \\
\hline $\mathrm{F}_{2}$ & 48.55 & 48.20 & 6.26 & 19.93 & 1.93 & 0.455 & 7.66 & 8.65 \\
\hline $\mathrm{F}_{3}$ & 49.18 & 49.54 & 6.30 & 21.14 & 1.35 & 0.512 & 8.28 & 17.44 \\
\hline $\mathrm{F}_{4}$ & 49.26 & 50.54 & 6.33 & 22.58 & 1.18 & 0.530 & 8.36 & 18.58 \\
\hline LSD (0.05) & ns & ns & ns & 2.36 & 0.2457 & 0.0266 & 0.104 & - \\
\hline CV (\%) & 3.64 & 2.93 & 5.43 & 4.71 & 13.37 & 6.63 & 4.07 & - \\
\hline
\end{tabular}

\section{Irrigation and disease incidence}

Irrigation had insignificant effect on disease incidence of onion (Table 1). Though disease incidence was not significantly influenced by the irrigation but a decreasing trend was observed with the increasing frequency of irrigation. However, disease infection was found maximum (score: 2.0) in non-irrigated control treatment, while it was minimum (score: 1.60) in treatment $1_{2}$ that received a total of 6 irrigations at 10 days interval. 
Table 2. Combined effects of irrigation and fungicide spray on yield, yield components and disease incidence of onion (average of 2 years).

\begin{tabular}{l|c|c|c|c|c|c|c}
\hline Treatment & $\begin{array}{c}\text { Plant } \\
\text { population } \\
(\text { no./m })\end{array}$ & $\begin{array}{c}\text { Plant } \\
\text { height } \\
(\mathrm{cm})\end{array}$ & $\begin{array}{c}\text { Leaves/ } \\
\text { plant } \\
\text { (no.) }\end{array}$ & $\begin{array}{c}\text { Unit bulb } \\
\text { wt } \\
(\mathrm{g})\end{array}$ & $\begin{array}{c}\text { Disease } \\
\text { score } \\
\text { (Scale:0-5) }\end{array}$ & $\begin{array}{c}\text { Biomass } \\
\text { yield } \\
\text { (t/ha) }\end{array}$ & $\begin{array}{c}\text { Bulb } \\
\text { yield } \\
\text { (t/ha) }\end{array}$ \\
\hline $1_{1} \mathrm{~F}_{1}$ & 48.55 & 40.70 & 5.10 & 11.86 & 3.16 & 0.232 & 3.44 \\
$1_{1} \mathrm{~F}_{2}$ & 48.27 & 39.60 & 4.60 & 12.06 & 2.00 & 0.25 & 3.82 \\
$1_{1} \mathrm{~F}_{3}$ & 48.84 & 41.53 & 4.80 & 12.50 & 1.50 & 0.273 & 4.07 \\
$1_{1} \mathrm{~F}_{4}$ & 48.82 & 43.22 & 5.00 & 13.28 & 1.33 & 0.290 & 4.18 \\
$1_{2} \mathrm{~F}_{1}$ & 48.79 & 54.53 & 7.26 & 27.06 & 2.33 & 0.618 & 10.25 \\
$1_{2} \mathrm{~F}_{2}$ & 49.22 & 53.83 & 7.60 & 27.61 & 1.75 & 0.683 & 11.11 \\
$1_{2} \mathrm{~F}_{3}$ & 48.99 & 55.16 & 7.43 & 30.29 & 1.24 & 0.790 & 12.23 \\
$1_{2} \mathrm{~F}_{4}$ & 49.66 & 55.73 & 7.20 & 31.09 & 1.08 & 0.807 & 12.45 \\
$1_{3} \mathrm{~F}_{1}$ & 49.22 & 53.66 & 7.06 & 21.87 & 2.83 & 0.477 & 8.40 \\
$1_{3} \mathrm{~F}_{2}$ & 48.99 & 51.93 & 7.10 & 22.45 & 1.83 & 0.537 & 9.18 \\
$1_{3} \mathrm{~F}_{3}$ & 49.88 & 53.41 & 7.03 & 23.70 & 1.33 & 0.583 & 9.86 \\
$1_{3} \mathrm{~F}_{4}$ & 49.27 & 53.98 & 7.43 & 25.43 & 1.16 & 0.600 & 10.04 \\
$\mathrm{~L}_{4} \mathrm{~F}_{1}$ & 48.60 & 47.06 & 5.40 & 16.62 & 3.00 & 0.300 & 6.08 \\
$1_{4} \mathrm{~F}_{2}$ & 47.71 & 47.43 & 5.70 & 17.63 & 2.16 & 0.350 & 6.60 \\
$1_{4} \mathrm{~F}_{3}$ & 49.00 & 48.06 & 5.93 & 18.09 & 1.33 & 0.400 & 6.97 \\
$1_{4} \mathrm{~F}_{4}$ & 49.27 & 49.23 & 5.76 & 20.52 & 1.16 & 0.457 & 7.60 \\
\hline $\mathrm{LSD}_{2}(0.05)$ & $\mathrm{ns}$ & 2.43 & 0.5739 & 0.5053 & 0.4913 & 0.0532 & 0.6076 \\
$\left.\mathrm{CV}_{2} \%\right)$ & 3.64 & 2.93 & 5.43 & 4.71 & 13.37 & 6.63 & 4.07 \\
\hline & & & & & & & \\
\hline
\end{tabular}

Unlike irrigation, fungicide spray had significant effect on the incidence of disease. Disease severity showed a significant negative correlation $\left(r^{2}=0.99\right)$ with the fungicide spray (Fig. 1), that is with the increase in number of sprays, there was a corresponding decrease in disease severity. But the disease severity was reduced at a decreasing rate with increasing number of sprays. However, the incidence was found maximum (score: 2.83) in unsprayed control plots, while it was minimum (score: 1.18 ) in the treatment sprayed three times $\left(\mathrm{F}_{4}\right)$ and it was statistically similar (score: 1.35 ) to the treatment sprayed two times $\left(\mathrm{F}_{3}\right)$. The yield increase in the sprayed treatments over the unsprayed control treatment ranged from $8.65 \%$ for $\mathrm{F}_{2}$ to as high as $18.58 \%$ for $\mathrm{F}_{4}$.

The combined effect of irrigation and fungicide spray showed significant influence on disease incidence (Table 2). The disease severity between sprayed and unsprayed plots ranged from 1.33 to 3.16 for $\mathrm{I}_{1}, 1.08$ to 2.33 for $1_{2}, 1.16$ to 2.83 for $1_{3}$ and 1.16 to 3.00 for $1_{4}$, respectively. Disease severity was recorded highest (score: 3.16 ) in the treatment received no irrigation and no spray $\left(1_{1} \mathrm{~F}_{1}\right)$ 
while it was the lowest (score: 1.08) in treatment that received a total of six irrigations and three sprays $\left(1_{2} \mathrm{~F}_{4}\right)$. The treatment combination of $1_{2} \mathrm{~F}_{4}$ produced the highest bulb yield (12.45 t/ha) with least disease incidence and the combination $\mathrm{I}_{1} \mathrm{~F}_{1}$ produced the lowest bulb yield (3.44 t/ha) of onion with the highest incidence of disease.

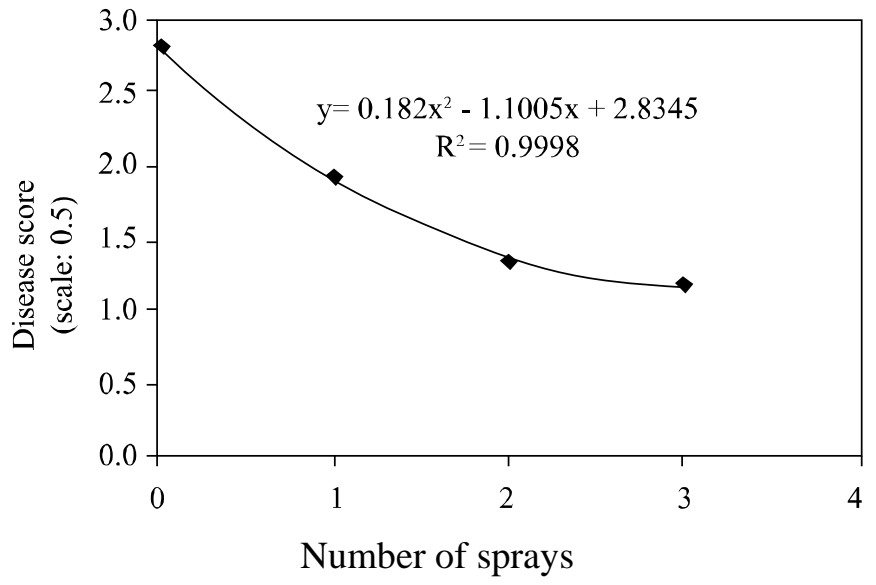

Fig. 1. Correlation between fungicide spray and disease severity.

\section{Total water used and water use efficiency}

Total water use and water use efficiency of onion is shown in Table 3. Total water use varied with the variation of the amount of irrigation water applied to the plots and soil water depletion; and it was found the maximum $(245 \mathrm{~mm})$ in treatment $1_{2}$, while it was the minimum $(102 \mathrm{~mm})$ in non-irrigated control treatment $\mathrm{I}_{1}$. Soil moisture depletion was inversely related to the amount of irrigation water applied.

Table 3. Total water use and water use efficiency as influenced by different levels of irrigation (average of 2 years).

\begin{tabular}{|c|c|c|c|c|c|c|c|c|}
\hline \multirow[t]{2}{*}{ Treatments } & \multirow{2}{*}{$\begin{array}{c}\text { No. of } \\
\text { irrigations }\end{array}$} & \multicolumn{2}{|c|}{ Amount of water applied } & \multirow{2}{*}{$\begin{array}{l}\text { Effective } \\
\text { rainfall } \\
(\mathrm{mm})\end{array}$} & \multirow{2}{*}{\begin{tabular}{|c|} 
Soil \\
moisture \\
depletio \\
$\mathrm{n}(\mathrm{mm})$
\end{tabular}} & \multirow{2}{*}{\begin{tabular}{|l|} 
Total \\
water \\
used \\
$(\mathrm{mm})$
\end{tabular}} & \multirow{2}{*}{$\begin{array}{c}\text { Bulb } \\
\text { yield } \\
\text { (kg/ha) }\end{array}$} & \multirow{2}{*}{\begin{tabular}{|c} 
Water use \\
efficiency \\
$(\mathrm{kg} / \mathrm{ha} / \mathrm{m}$ \\
$\mathrm{m})$
\end{tabular}} \\
\hline & & $\begin{array}{c}\text { For plant } \\
\text { establishm } \\
\text { ent }(\mathrm{mm})\end{array}$ & \begin{tabular}{|c} 
After plant \\
establishment \\
$(\mathrm{mm})$
\end{tabular} & & & & & \\
\hline $\mathrm{I}_{1}$ & 0 & 30 & 0 & 26 & 46 & 102 & 3870 & 37.94 \\
\hline $\mathrm{I}_{2}$ & 6 & 30 & 172 & 16 & 27 & 245 & 11520 & 47.02 \\
\hline $\mathrm{I}_{3}$ & 3 & 30 & 124 & 16 & 29 & 199 & 9370 & 47.08 \\
\hline $\mathrm{I}_{4}$ & 2 & 30 & 96 & 16 & 30 & 169 & 6810 & 40.29 \\
\hline
\end{tabular}

The highest amount of irrigation water $(202 \mathrm{~mm})$ was required in the treatment $\mathrm{I}_{2}$ which received a total of six irrigations each at 10 days interval. The water use pattern by different treatments was like that as higher the number of 
irrigation the less the amount of water needed in each irrigation (Table 3). Though total water use was the highest in treatment $1_{2}$, the highest water use efficiency $(47.08 \mathrm{~kg} / \mathrm{ha} / \mathrm{mm})$ was recorded in treatment $1_{3}$ with total water use of $199 \mathrm{~mm}$ (Table 3). However, the lowest water use efficiency $(37.94 \mathrm{~kg} / \mathrm{ha} / \mathrm{mn})$ was recorded in non-irrigated control treatment as the plants of this treatment suffer from shortage of water and thereby did not produce better yield.

\section{Conclusion}

Disease incidence of onion did not vary significantly by irrigation frequencies. But there was a decreasing trend in disease severity with increasing number of irrigation under the tested irrigation sequences of no irrigation to six irrigations. Unlike irrigation, fungicide spray had significant influence on disease incidence. Disease severity was found the minimum by spraying fungicide for three times. The yield of onion increased almost linearly with irrigation. The highest bulb yield was obtained from the treatment which received a total six irrigations at 10 days interval. So it is evident that frequent irrigation (10 days interval) along with 3 sprays may be the optimal practice for onion production in Jessore area. However, an irrigation interval of less than 10 or in between 10 and 20 days (e.g.,15 days) may be tested for further confirmation of the suitable irrigation intervals.

\section{References}

Ahmed, H.U. and M.M. Hossain. 1985. Final report of the project, crop disease survey and establishment of a herbarium at BARI, Plant Path. Divn., BARI, Joydebpur, Gazipur. p. 170.

Ashrafuzzaman, M.H. and M.U. Ahmad. 1976. Control of foliage disease of onion by spraying fungicides. Bangladesh Hort. 4(2): 28-30.

BBS. 2004. Statistical Year Book of Bangladesh, Bangladesh Bureau of Statistics, Planning Division, Ministry of Planning, Govt. of the People's Republic of Bangladesh, Dhaka, Bangladesh. p.143.

Biswas, S.K., P.K. Sarker, A.K.M. Mazharul Islam, M.A. Bhuiyan and B.C. Kundu. 2003. Effect of irrigation on onion production. Pakistan J. Bio. Sci. 6(20): 17251728.

Bose, T.K. and G.M. Some. 1986. Vegetable crops in India. Naya Prakash, Calcutta, India. pp. 567-569.

FAO. 2001. Quarterly Bulletin of Statistics, Food and Agricultural Organization of the United Nations, Rome, Italy. 2(2): 97.

Ghuge, S.S., C.D. Mayee, and G.M. Godbole. 1980. Assessment of losses in groundnut due to rust and tikka leaf spot. Indian Phytopath. (Abstract). 33: 163.

Islam, M.S., B.R. Khan and M.H. Rashid. 1997. Irrigation scheduling for onion. Bangladesh J. Agril. Res. 24: 233-240. 
Meah, M.B. and A.A. Khan. 1987. Check list of fruit and vegetable diseases in Bangladesh. Dept. of Plant Pathology, BAU, Mymensingh. p.23.

Rahman, M.L., H.U. Ahmed and I.H. Mian. 1988. Efficacy of fungicides in controlling purple leaf blotch of onion. Bangladesh J. Plant Path. 4(1\&20): 71-76.

Sharma, S.R. 1986. Effect of fungicidal sprays on purple blotch and bulb yield of onion. Indian Phytopath. 39(1): 78-82. 